\title{
A LUTA PELA TERRA NO MUNICÍPIO DE FEIRA DE SANTANA-BA: CONSIDERAÇÕES SOBRE ALGUNS LIMITES LEGAIS PARA A REFORMA AGRÁRIA ${ }^{1}$
}

\section{THE FIGHT FOR EARTH IN THE MUNICIPALITY OF FAIR DE SANTANA-BA: CONSIDERATIONS ON SOME LEGAL LIMITS FOR AGRARIAN REFORM}

\author{
José Roberto Silva de SOUZA ${ }^{2}$ \\ José Raimundo de Oliveira LIMA ${ }^{3}$
}

\begin{abstract}
Resumo:O presente trabalho analisa a situação sociojurídica de famílias acampadas em uma fazenda pertencente ao Estado da Bahia. A propriedade foi, no passado, utilizada por uma empresa pública denominada Empresa Baiana de Desenvolvimento Rural (EBDA), como uma estação experimental, para desenvolvimento de assistência técnica, pesquisa e extensão agrícola. Metodologicamente, utilizamos como sustentação documental o estudo da legislação, a proposta de reforma agrária oferecida pelo MST,bem como outros documentos que estão diretamente relacionados ao históricoda propriedade. Assim, levantamos e analisamos dados e informações sobre a titulação da propriedade, a legislação urbana de Feira de Santana, município em que está situado o acampamento, e também sobre o plano diretor do município, consubstanciando o texto com elementos importantes da realidade feirense, principalmente, no que se refere a sua localização, por se tratar de uma área de terra onde está assentado um acampamento do Movimento dos Trabalhadores Rurais Sem Terra (MST). Assim, esta pesquisa se debruça sobre a realidade dos assentados, cuja coleta de informações foi realizada através da entrevista semiestruturada. Com efeito, infere-se que, por ser terra pública, transformar a fazenda em assentamento se tornaum grande desafio, uma vez que os bens públicos estão submetidos a uma legislação mais complexa.
\end{abstract}

Palavras-chave: Terra Públicas; Reforma Agrária; Assentamento.

\begin{abstract}
The present work analyzes the socio-legal situation of families camped on a farm belonging to the State of Bahia. The property was, in the past, used by a public company called Empresa Bahiana de Desenvolvimento Rural (EBDA), as an experimental station, for the development of technical assistance, research and agricultural extension. Methodologically, we used as a documentary support the study of the legislation, the proposed agrarian reform offered by the MST, as well as other documents that are directly related to the history of the property. Thus, we collected and analyzed data and information on the title of the property, the urban legislation of Feira de Santana, the municipality where the camp is located, and also on the municipality's master plan, consolidating the text with important elements of the reality of the fair, mainly, with regard to its location, as it is an area of land where a camp of the Landless Rural Workers Movement (MST) is based. Thus, this research focuses on the reality of the settlers, whose information collection was carried out through the semi-structured
\end{abstract}

\footnotetext{
${ }^{1}$ Trabalho resultado de pesquisa avaliada e aprovada pelo Comitêde Ética em Pesquisa (CEP), com título "O MST E A LUTA POR REFORMA AGRÁRIA EM FEIRA DE SANTANA: uma alternativa para o Acampamento Estrela Vive que passa por uma outra economia.

${ }^{2}$ Graduado em Direito pela Universidade Estadual de Feira de Santana. Mestrando do Programa de PósGraduação em Planejamento Territorial da Universidade Estadual de Feira de Santana. E-mail: zerobertouefs@gmail.com

3 Doutor em Educação e Contemporaneidade pelo PPGDUC(2014) e Mestre em Gestão Integrada de Organizações (2003) pela Universidade do Estado da Bahia (UNEB). Possui especialização em Gestão organizacional (2000) e Graduação em Ciências Econômicas (1998) pela Universidade Estadual de Feira de Santana (UEFS), onde atua como professor Titular. E-mail: zeraimundo@uefs.br
} 
interview. Indeed, it is inferred that, as it is public land, transforming the farm into a settlement becomes a major challenge, since public goods are subject to more complex legislation.

Keywords: Public Land; Land reform; Settlement.

\section{Introdução}

Este trabalho é resultado de uma pesquisa qualitativa submetida e aprovada pelo Comitê de Ética em Pesquisa (CEP), realizada em uma ocupação do Movimento dos Trabalhadores Rurais Sem Terra (MST), numa área de terra,que na década de 1930, foi comprada pelo Estado da Bahia,tendo sido transferida nos anos 80 paraa extinta Empresa Baiana de Desenvolvimento Rural (EBDA), atualmente, a Secretaria de Administração do Estado da Bahia (SAEB).

A já liquidada EBDA era uma empresa pública de direito privado, sob forma de sociedade anônima, havia sido constituída com base na Lei Delegada n. ${ }^{\circ} 16$, de 16 de abril de 1981, que administrava a Estação Experimental Fazenda Cruzeiro do Mocó, no município de Feira de Santana.

A empresa não exercia, e não exerce atualmente, exploração econômica. Dedicava-se exclusivamente à prestação de serviços de assistência técnica, pesquisa e extensão agrícola, atuando sozinha ou em conjunto com outros órgãos estaduais, federais e municipais, procurando implantar projetos sociais de desenvolvimento agrário no Estado da Bahia.

Esta fazenda tem atualmente, instalado em suas dependências, o acampamento Estrela Vive do Movimento dos Trabalhadores Rurais Sem Terra, que enfrenta uma série de desafios de natureza política e administrativa, em busca da transformação desta área em um assentamento de reforma agrária.

Dentre os desafios que enfrentamos no decorrer deste trabalho, está a condição agrária deste imóvel, uma vez que o mesmo é terra pública pertencente ao Estado da Bahia, o que demandou estudos de direito agrário brasileiro, através dos quais buscamos respostas sobre como agir para realizar o sonho de assentamento daquelas famílias. O MST, ao ocupar a área, tinha ciência de que se tratava de terra pública, uma vez que a terra estava sendo "abandonada" por uma empresa pertencente ao Estado.

Desta forma, esta pesquisa resgata a importância da reforma agrária, tendo como elemento peculiar a condição de patrimônio público da área em questão, o que demandará para o assentamento das famílias ali acampadas, ações junto ao estado da Bahia, as quais iremos discutir no decorrer deste trabalho.

Diante do exposto, uma indagação se apresenta: quais obstáculos se impõem no desafio de assentar famílias em uma fazenda de 582 hectares de terra pública pertencente ao Estado da Bahia? Perante esse questionamento, focamos noobjetivo de discutir as limitações legislativas da administração pública do Estado da Bahia para criar um assentamento rural na terra pública localizada no município de Feira de Santana. Assim, para dar conta do objetivo central,foi necessárioestabelecer alguns objetivos específicos, como: i) compreender o significado de terras públicas no Brasil; ii) analisar as leis brasileiras; iii) estudar a questão agrária no Brasil e seus reflexos no caso específico de Feira de Santana.

Metodologicamente, o estudo tem sustentação teórica em referências aderentes apontando autores que já trabalharam com a temática da questão agrária, além de estudos documentais que indicam os dispositivos da legislação brasileira e do Estado da Bahia para fundamentar nossa posição e dar sustentação sobre o fenômeno em pesquisa. Para dar maior sustentação aos dados da pesquisa e por se tratar de uma área de terra onde está localizado um acampamento do Movimento dos Trabalhadores Rurais Sem Terra - MST, afastada dos 
ambientes urbanos (Distrito de Jaguara e Cidade de Feira de Santana), onde esta pesquisa se debruça sobre a realidade dos assentados, lançamos mão também do instrumento de entrevista semiestruturada.

O proponente desta pesquisa busca desenvolver o que Minayo (2009) chama de Pesquisa Social, uma vez que existe, neste caso, uma identidade entre o sujeito e o seu objeto de estudo, ou seja, um movimento social que luta por terra, no qual o próprio pesquisador engrossa suas fileiras participando de atividades organizadas em diversas partes do Estado da Bahia e no próprio acampamento em Feira de Santana.

Minayo (2009) nos fala de uma dimensão muito importante da pesquisa, ao anunciar que

$\mathrm{Na}$ investigação Social, a relação entre o pesquisador e o seu campo de estudo se estabelece definitivamente. A visão de mundo de ambos está implicada em todo processo de conhecimento, desde a concepção do objeto aos resultados do trabalho e à sua aplicação. (MINAYO, 2009, p.13)

A metodologia que adotamos está completamente alinhada com os ensinamentos de Minayo (2009), quando conceitua a metodologia como

O caminho do pensamento e prática exercida na abordagem da realidade. Ou seja, a metodologia inclui simultaneamente a teoria da abordagem (o método), os instrumentos de operacionalização do conhecimento (as técnicas) e criatividade do pesquisador (sua experiência, sua capacidade pessoal e sua sensibilidade). (MINAYO, 2009, p.14).

Essa reflexão nos dáuma noção mais abrangente sobre os caminhos que teremos pela frente no interesse de produzir este trabalho,orientando-nos pelos princípios da pesquisa social.

Há um processo judicial em andamento, que servirá como fonte de informação sobre dados da fazenda e da própria EBDA, uma vez que este tem diversos documentos importantes anexados.

Lançamos mão dedados da titulação da propriedade, além de informações da legislação urbana de Feira de Santana e do Plano Diretor do município, enriquecendo o texto com elementos importantes da realidade feirense, principalmente, no que se refere à localização da Estação Experimental.

No processo de coleta de dados, utilizamos a entrevista, um instrumento metodológico que, sendo um preceito fundamental da pesquisa social, contribuiu para o enriquecimento do nosso trabalho através da análise dos dados obtidos. De acordo com Minayo (2009, p.64), a "entrevista é acima de tudo uma conversa a dois, ou entre vários interlocutores, realizada por iniciativa do entrevistador". Nesse sentido, os dados obtidos por meio desse instrumento foram uma referência importante no nosso trabalho.

Por se tratar de um material discutido organicamente entre os estudiosos e muito útil ao Processo Político Educativo do Movimento, a cartilha de estudos do MST, utilizada como fonte depropagação de sua base política, também foi analisada paraajudar na compreensão sobre determinados fenômenos,cujotema que propõe um novo modelo de reforma agrária, classificada como reforma agrária popular, se tornou foco do nosso interesse.

Com efeito, este artigo foiestruturado, além da introdução e das considerações finais, dos seguintes eixos temáticos: i) terras públicas no Brasil: uma compreensão necessária; ii) leis brasileiras sobre terras - uma síntese e, por fim, iii) a questão agrária no Brasil: considerações sobre alguns limites legais da luta pela terra no município de Feira de SantanaBA. 
EM

QUESTÃO

\section{Terras públicas no Brasil: uma compreensão necessária}

A Empresa Baiana de Desenvolvimento Agrícola - EBDA foi criada para prestar serviços de assistência técnica, extensão rural e pesquisa agropecuária no Estado da Bahia. Extinta pelo decreto $\mathrm{n}^{\circ} 17.037$ de 23 de setembro de 2016, chegou a atuar em 417 municípios baianos, atendendo em média 316.000 agricultores em toda Bahia.A extinção da empresa foi autorizada pela Lei 13.204 de 11 de dezembro de 2014, a qual, no seu artigo 35, II, diz:

Art. 35 Fica o Poder Executivo autorizado a praticar os atos necessários à extinção:

Il - da Empresa Baiana de Desenvolvimento Agrícola S.A. - EBDA, Sociedade de Economia Mista, vinculada à Secretaria de Agricultura, Pecuária, Irrigação, Reforma Agrária, Pesca e Aquicultura - SEAGRE.

(BAHIA, 2014).

Toda a sua estrutura fora liquidada pelo poder público baiano, ficando todos os bens imóveis recepcionados pela Secretaria de Administração do Estado da Bahia - SAEB, conforme aponta o decreto supracitado em seu artigo 3.':

Art. $3^{\circ}$ - A SAEB, através da Superintendência de Patrimônio, recepcionará todos os bens imóveis das empresas extintas, conforme inventários apresentados pelos liquidantes, providenciando a regularização da titulação, porventura pendente, bem assim a sua avaliação e regularização contábil, integrando-os ao acervo patrimonial do Estado da Bahia. (BAHIA,2016).

A Estação Experimental, ocupada pelo MST em 2009, fora fixada dentro de um desses imóveis pertencentes à extinta EBDA, transferida pelo referido decreto à SAEB em 2016.

No dia 16 de março de 2009, famílias organizadas pelo MST, advindas de diversos bairros da cidade de Feira de Santana, ocuparam a propriedade na esperança de um dia serem assentadas na área, e assim, poderem trabalhar e produzir suas existências.

\section{Método de apropriação da área}

Procuraremos demonstrar aqui como as famílias se apropriaram da fazenda.Apresentaremos elementos tirados da entrevista aplicada no acampamento, instrumento que foi autorizado pelo Conselho de Ética em Pesquisa (CEP), através de aprovação de projeto avaliado pelo órgão.

Importante esclarecer que ao ocupar a propriedade, as famílias iniciaram todo um processo de apropriação dos limites e das divisas da fazenda. Inicialmente, cada família acampada construiu barracos de lonas pretas e madeira para servir de abrigo aos componentes da família.

Antes da montagem dos barracos, as famílias se reuniram para decidir sobre o local da construção, a proposta era que cada dez famílias se transformassem num grupo por proximidade, construindo os barracos uns ao lado dos outros, para facilitar a comunicação entre o grupo.

Fixados os grupos de dez famílias, os barracos em seus devidos lugares, iniciou-se um processo de organização política interna do acampamento. Cada grupo, composto por 10 famílias, deveria apontar, entre eles, pessoas para assumir algumas tarefas existentes no acampamento. 
É importante ressaltar que cada família acampada geralmente era composta de no mínimo 4 integrantes, considerando a existência de algumas famílias com mais integrantes, isto significa dizer que cada grupo de família possuía uma média de 40 pessoas.

Cada tarefa específica seria desenvolvida por um representante que fora eleito pelo grupo de 10 famílias. Essa tarefa específica também era conhecida como setor. Então, para cada grupo de família existia um setor específico como: setor de saúde, deeducação, de juventude, de gênero, de disciplina, de produção, de comunicação, de formação, de trabalho e de coordenação. Todos os integrantes das famílias podiam participar das tarefas dos setores, não precisava ser o titular do cadastro no acampamento par exercê-las.

Sendo assim, cada grupo deveria conter no mínimo 11 pessoas que se responsabilizavam por tarefas, pois existia uma normativa interna, acordada entre eles, que cada setor deveria ter pelo menos um representante em cada grupo de família. É possível perceber que são 10 setores, 10 pessoas por grupo defamília, no entanto, quem compõe a coordenação desenvolve papel de liderança internamente, composta sempre por duas pessoas, sendo obrigatoriamente um homem e uma mulher.

Outra atividade, aqui não mencionada como setor, mas que possuía dimensões mais amplas e fugia um pouco da organicidade exclusiva do grupo de família, se configurava como uma espécie de mutirão reunindo todos os grupos para realização de alguns trabalhos necessários no acampamento. Conhecido como "coletivo", este grupo realizava algumas tarefas que demandavam muito trabalho, como limpeza das estradas internas do acampamento, limpeza das estruturas físicas deixadas pela EBDA, serviços de jardinagem nas árvores plantadas à beira das estradas internas, limpeza de açudes, plantação de roça para pessoa jurídica da qual são associados, dentre outras.

Após a construção dos barracos, organização dos setores e definição dos representantes de cada grupo, seguia-se à formulação dos calendáriosde cada grupo de família, que ajudam na realizaçãodas tarefas específicas de cada área. A coordenação é responsável por reunir o grupo a que pertence para encaminhar as demandas das famílias.

Os grupos de famílias também têm seu próprio calendário, reunindo-se regularmente para que cada pessoa integrante do grupo se mantenha informado dos eventos que ocorrem no acampamento, dos encaminhamentos dos setores, da coordenação e também para que cada integrante proponha algo que ache importante.

Esse modelo de organização objetiva facilitar o processo de mobilização e de formação de consciência social dos acampados, ao mesmo tempo em que permite que grande parte das pessoas se vejam responsáveis pelo acampamento, participando ativamente das mais diversas ações cotidianas da comunidade.

Quadro 1-Organização do Acampamento Estrela Vive

\begin{tabular}{|c|c|c|}
\hline \multicolumn{3}{|c|}{ ACAMPAMENTO ESTRELA VIVE } \\
\hline \multicolumn{3}{|c|}{ 10 GRUPOS DE FAMílIAS } \\
\hline COORDENAÇÃO & SETORES & SETOR REGIONAL \\
\hline $\begin{array}{c}\text { 02 pessoas por grupo de } \\
\text { família }\end{array}$ & $\begin{array}{c}\text { 01 pessoa para cada um dos } 9 \\
\text { setores em cada grupo de } \\
\text { família }\end{array}$ & $\begin{array}{c}\text { 02 pessoas para cada setor } \\
\text { regional entre as 10 pessoas de } \\
\text { cada um dos 10 setores }\end{array}$ \\
\hline 20 pessoas envolvidas & 90 pessoas envolvidas & 20 pessoas envolvidas \\
\hline
\end{tabular}

Fonte: Criação do autor. Março/2020

Essas famílias que compõem oacampamento Estrela Vive fazem parte de um corpo organizativo maior, chamado de Brigada, que é composta por outros acampamentos e assentamentos existentes atingindo três municípios do Recôncavo Baiano - Feira de Santana, 
Santo Amaro e Santo Estevão. A Brigada foi batizada, pelas coordenações das áreas, com o nome Carlos Marighella em homenagem a um baiano que morreu lutando contra a ditadura militar.

O MST reproduz essa prática em todo lugar por onde passa, homenageia diversos lutadores do povo, dando aos acampamentos e assentamentos o nome desses heróis que tombaram lutando pelos pobres e oprimidos. No Estado da Bahia, são mais de dez brigadas com diversos nomes de lutadores, em um esforço de lembrarem esses heróis, para que sua memória permaneça.

Desta forma, cada acampamento e assentamento que integra a brigada Carlos Marighella deve eleger dois representantes do acampamento para a coordenação do Recôncavo, e mais duas pessoas por setor.

Neste sentido, temos a coordenação e os setores internos do acampamento para debater e encaminhar as demandas internas próprias, e temos uma coordenação e setores que participam de atividades externas, relacionando-se com os demais acampamentos e assentamentos, demandando também, pautas de cunho regional.

Apresentamos abaixo para facilitar a percepção da organicidade da brigada, um quadro analítico que demonstra os elementos de composição da mesma.

Quadro 2- Organização da Brigada Carlos Marighella

\begin{tabular}{|c|c|c|}
\hline \multicolumn{3}{|c|}{ REGIÃO DO RECONCAVO - BRIGADA CARLOS MARIGHELLA } \\
\hline $\begin{array}{c}\text { ACAMPAMENTO FEIRA } \\
\text { DE SANTANA }\end{array}$ & $\begin{array}{c}\text { ACAMPAMENTO SANTO } \\
\text { ESTEVÃO }\end{array}$ & $\begin{array}{c}\text { ACAMPAMENTO SANTO } \\
\text { AMARO }\end{array}$ \\
\hline $\begin{array}{c}\text { 02 pessoas para coordenação } \\
\text { regional }\end{array}$ & $\begin{array}{c}\text { 02 pessoas para coordenação } \\
\text { regional }\end{array}$ & $\begin{array}{c}02 \text { pessoas para coordenação } \\
\text { regional }\end{array}$ \\
\hline $\begin{array}{c}\text { Duas pessoas para o setor } \\
\text { regional de cada um dos } 10 \\
\text { setores do acampamento }\end{array}$ & $\begin{array}{c}\text { Duas pessoas para o setor } \\
\text { regional de cada um dos } 10 \\
\text { setores do acampamento }\end{array}$ & $\begin{array}{c}\text { Duas pessoas para o setor } \\
\text { regional de cada um dos } 10 \\
\text { setores do acampamento }\end{array}$ \\
\hline $\begin{array}{c}\text { 22 pessoas representando o } \\
\text { acampamento }\end{array}$ & $\begin{array}{c}22 \text { pessoas representando o } \\
\text { acampamento }\end{array}$ & $\begin{array}{c}22 \text { pessoas representando o } \\
\text { acampamento }\end{array}$ \\
\hline
\end{tabular}

Fonte: Criação do autor. Março/2020

\section{Localização}

Torna-se necessário um estudo sobre a localização do imóvel dentro do município de Feira de Santana,tendo em vista que foi aprovada a expansão urbana da cidade, nas esferas do legislativo e do executivo.

Em 2013, a área urbana do município de Feira de Santana foi expandida pela Lei 075/2013 que ampliou geograficamente os limites da urbanização.A lei criou dentre outras coisas, 6 novos bairros, assim expresso nos artigos $3 .^{\circ}$ e $4 .^{\circ}$ conforme texto abaixo

Art. $3^{\circ}$ Os limites dos 06 (seis) novos Bairros inseridos no Perímetro Urbano de Feira de Santana se encontram estabelecidos através desta Lei, conforme mapeamento apresentado no TÍTULO IV - ANEXOS, desta Lei, se constituindo em sua parte integrante. Art. $4^{\circ}$ Os novos Bairros de Feira de Santana são os seguintes: 045 - VALE DO JACUÍPE; 046 - PEDRA FERRADA; 047 - CIS NORTE; 048 - MANTIBA; 049 - REGISTRO; 050 CHAPARRAL. (FEIRA DE SANTANA, 2013). 
Ao refletir sobre o Projeto de Lei Municipal do Plano Diretor de Desenvolvimento Urbano e Territorial de Feira de Santana (2018), no título VIII do Ordenamento Territorial, iremos perceber que dentre os objetivos específicos existe a definição de uma nova divisão territorial, assim expresso no artigo 173, I, do Projeto.

O projeto utiliza um instrumento chamado de macrozoneamento, estabelecendo o conceito no artigo 180, vejamos:

Art. $180 \mathrm{O}$ macrozoneamento é o instrumento que define a estruturação e divisão territorial, urbano e rural, face às ações estratégicas de desenvolvimento urbano, rural e socioeconômico estabelecidas para o período de vigência do Plano Diretor, configurando-se como referência a ser observada pelo Poder Público e para o controle social.(FEIRA DE SANTANA, 2018).

Este instrumento criou uma série de espaços no município, dentre esses espaços, a chamada de Macroárea de Expansão Urbana que tem a seguinte conceituação:

Art. 194 A Macroárea de Expansão Urbana define-se como espaço territorial de ampliação do tecido urbano da cidade de Feira de Santana, proporcionando novas dinâmicas.

Parágrafo único - Caracteriza-se como um avanço da malha urbana, prioritariamente para os sentidos nordeste e sudeste do território, avançando pela zona rural da sede, até atingir os limites domunicípio, na margem direita do rio Pojuca, e, como segundo vetor de expansão, pelo lado oeste, seguindo pelo Vale do Jacuípe, nas cercanias do condomínio Alphaville.(FEIRA DE SANTANA, 2018).

Nesta Macroárea estão desenhados os novos bairros criados pela Lei 075/2013 citados anteriormente.A Estação Experimental Cruzeiro do Mocó tem divisas fronteiriças com um dos novos bairros criados pela Macroárea, Vale do Jacuípe, onde temos um limite entre o urbano e o rural.

O mapa de Feira de Santana abaixo, retirado do Projeto de leido Plano Diretor de Desenvolvimento Urbano e Territorial de Feira de Santana, já aprovado, demonstra essa expansão com a criação dos novos bairros:

Figura 01-Mapa do Município de Feira de Santana - Expansão Urbana

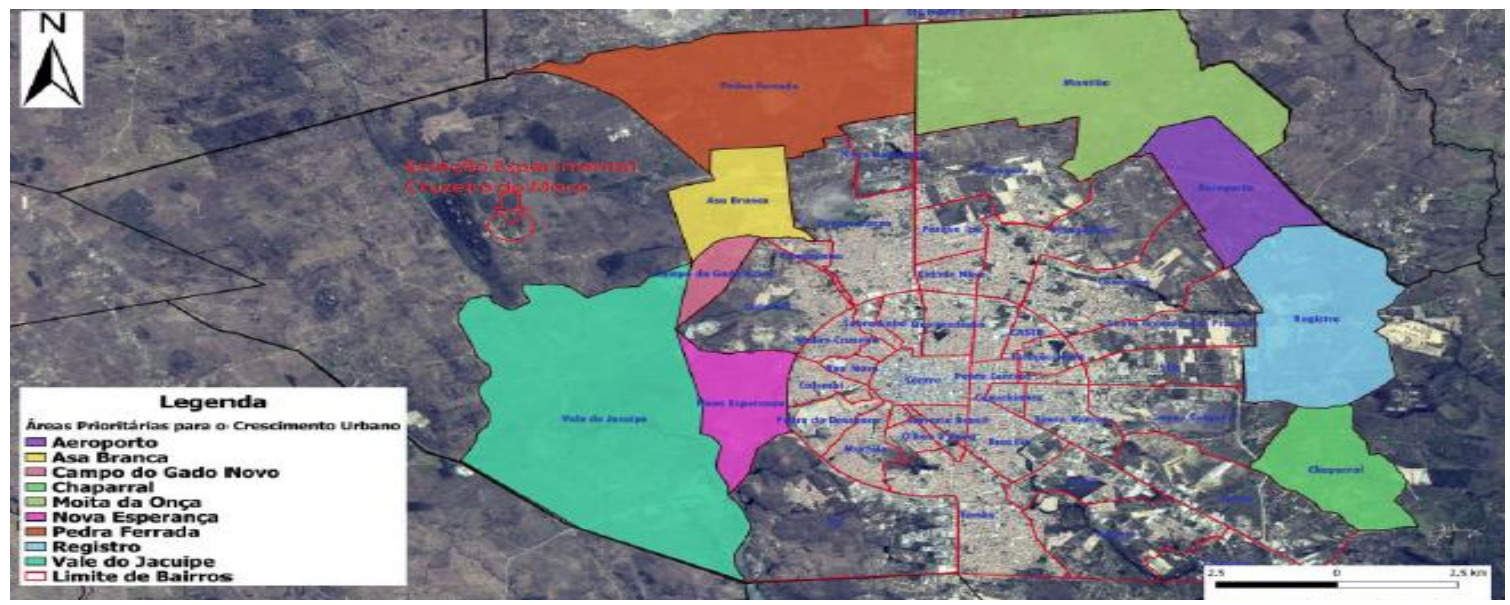

Fonte: Projeto de Lei Municipal do Plano Diretor de Desenvolvimento Urbano de Feira de Santana 2018. 
No mapa acima, as partes coloridas são os novos bairros criados. Nele, podemos observar que a Estação Experimental Cruzeiro do Mocó está fora do perímetro determinado pela Macroárea como área de expansão urbana, tendo desta forma, permanecida na zona rural do município.

Ocorre que a demora na definição desses espaços acarretou um retardamento nas discussões com administração pública do Estado baiano, uma vez que pairavam dúvidas sobre a localização dos limites da fazenda quanto a sua localização dentro dos limites da expansão territorial do município ou não.

Figura02 - Localização

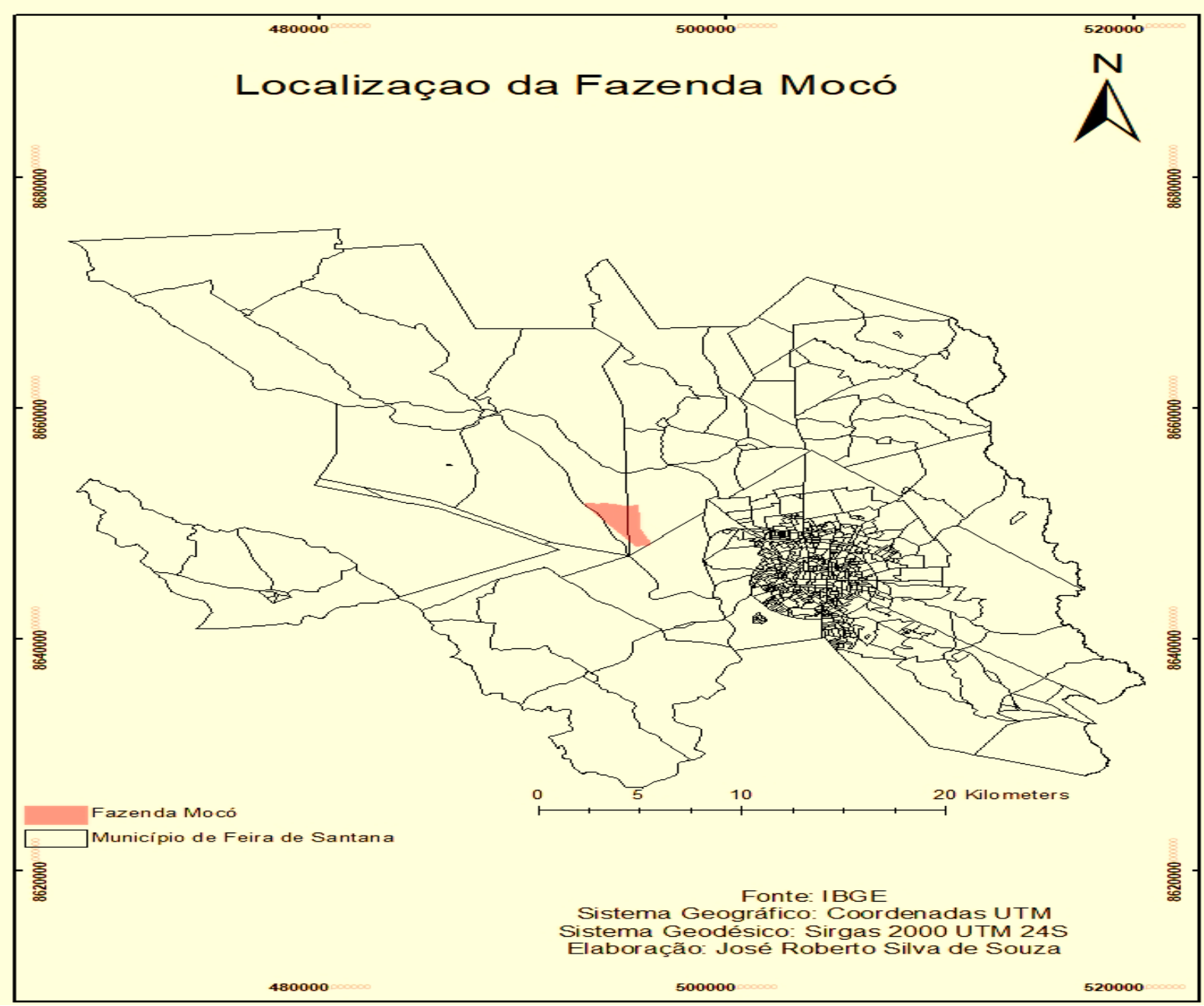

Fonte: Criação do autor. Março/2020

O mapa acima apresenta as coordenadas geográficas do acampamento, dando a localização exata do imóvel.

\section{Terra como bem público e terras devolutas}

Já sabemos, que atualmente, determinado por meio do decreto $\mathrm{n}^{\circ} 17.037$ de 23 de setembro de 2016, o imóvel de 582 hectares ocupado pelo MSTpertence à SAEB, sendo desta forma, considerada terra pública, uma vez que pertencente ao Estado da Bahia. 
$\mathrm{EM}$

Para sustentar que o imóvel é um bem público, Carvalho Filho (2015) afirma que são bens públicos

todos aqueles que, de qualquer natureza e a qualquer título, pertençam às pessoas jurídicas de direito público, sejam elas federativas, como a União, os Estados, o Distrito Federal e os Municípios, sejam da Administração descentralizada, como as autarquias, nestas incluindo-se as fundações de direito público e as associações públicas.(CARVALHO FILHO, 2015, p.1181).

De acordo com o registro de imóvel anexado aos autos do processo judicial movido contra as famílias acampadas na fazenda, esta área foi comprada pelo Estado juntamente com outros quatro imóveis, sendo as duas primeiras aquisições efetuadas no ano de 1938 e as duas outras em 1948, diga-se de passagem, que se trata de um período governado por Getúlio Vargas conhecido como "Estado Novo".

Em termos Jurídicos, a propriedade ocupada pelo MST é um bem público adquirido no mercado de terras para que atendesse a uma finalidade estatal, à época de sua aquisição, de desenvolvimento de pesquisa e extensão rural como visto na apresentação.

É preciso atentar para algumas questões que envolvem o conceito de bens público e, principalmente, no que se refere a um imóvel rural, pois esse tema resvala na condição da terra ocupada pelo movimento, haja vista sua condição de bem público, uma vez que no Brasil temos uma herança colonial, que historicamente vem sendo arrastada, sobretudo no que se refere às questões do direito agrário brasileiro.

No Brasil, em especial, as terras públicas, geralmente, são conhecidas juridicamente como terras devolutas, conceito desenvolvido por Marés

Terras devolutas, portanto, estavam definidas, e estão até hoje, por sua negação, quer dizer, devolutas são as terras que não são aplicadas a algum uso público, nacional, provincial ou municipal, não se achem no domínio particular, nem tivesse sido havidas por sesmarias e outras concessões do Governo Geral ou Provincial. (MARÉS 2003, p.73).

Ainda em vigência, a Lei $\mathrm{n}^{\circ} 601$, de 18 de setembro de 1850 , define em seu artigo $3 .^{\circ} \mathrm{o}$ significado de terras devolutas

Art. $3^{\circ}$ São terras devolutas: $\S 1^{\circ}$ As que não se acharem aplicadas a algum uso público nacional, provincial, ou municipal. $\S 2^{\circ}$ As que não se acharem no domínio particular por qualquer título legítimo, nem forem havidas por sesmarias e outras concessões do Governo Geral ou Provincial, não incursas em comisso por falta do cumprimento das condições de medição, confirmação e cultura. $\S 3^{\circ}$ As que não se acharem dadas por sesmarias, ou outras concessões do Governo, que, apesar de incursas em comisso, forem revalidadas por esta Lei. $\S 4^{\circ}$ As que não se acharem ocupadas por posses, que, apesar de não se fundarem em título legal, forem legitimadas por esta Lei. (BRASIL, 1850).

Desta maneira, entende-se que o imóvel aqui analisado, apesar de ser um bem público, não se trata de terra devoluta, uma vez que este era utilizado pelo estado para fins de desenvolvimento de pesquisa e extensão agrícola como uma tarefa estatal pública e de auxílio à agricultura no Estado da Bahia. 
Outra característica que retira a menção de terra devoluta é o fato do estado ter adquirido a mesma por meio de compra de vários outros proprietários, assim registrado no título da propriedade.

Mas, esta é uma afirmação que se encontra no passado, uma vez que hoje em dia, o imóvel não cumpre mais esta função, não sendo mais utilizado pela administração pública, ao menos, temporariamente, o que não dá a este o status de devoluta.

Nesta direção, podemos entender que terras devolutas são bens públicos, mas existem terras públicas que não são devolutas, pois o Estado deu uma função ou destino a esta ou a adquiriu no mercado.

O conceito de bens públicos é desenvolvido pelo Código Civil Brasileiro Lei n. ${ }^{\circ}$ 10.406 de 10 de janeiro de 2002 que no artigo 98 aduz

Art. 98. São públicos os bens do domínio nacional pertencentes às pessoas jurídicas de direito público interno; todos os outros são particulares, seja qual for a pessoa a que pertencerem. (BRASIL,2002).

Atualmente, os 582 hectares de terra daquela área encontram-se em desuso. O estado não tem dado qualquer utilidade àquele bem, encontra-sehá mais de 10 anos ocupada pelos Sem Terra, que por hora, contra a vontade da administração pública, está servindo para que as famílias trabalhem e produzam alimentos, reproduzindo desta forma suas existências.

Enquanto este bem estava sendo utilizado para um fim determinado, segundo algumas teorias do mundo jurídico, ele era tratado como "bem de uso especial", que de acordo com Carvalho (2017, p. 1089), são bens usados para a prestação de serviço público pela administração ou conservados pelo Poder Público com finalidade pública.

Todo bem público de uso especial, segundo doutrina jurídica, é um bem afetado, haja vista sua utilidade, poisde acordo com Carvalho (2017, p. 1090), afetar o bem é dar destinação pública. Sendo desta forma inalienável, ou fora do comércio, conformese confere abaixo:

Tradicionalmente, a doutrina costumava enumerar a inalienabilidade como característica básica de bens públicos. Tal regra, modernamente se aplica aos bens de uso especial e os de uso comum são afetados, logo insuscetíveis de alienação.(CARVALHO, 2017, p.1092).

Ao ser extinta, a EBDA, em sua liquidação, teve todo seu patrimônio imóvel transferido para SAEB. Sem ter dado qualquer função ao imóvel, ocorreu o fenômeno conhecido no direito por desafetação, que é definida por Carvalho (2017, p. 1094) como a ação de "suprimir a destinação de bem que estava atrelado, de alguma forma, ao interesse público".

Não ter instituído uma função utilitária para o imóvel, estando há mais de10 anos em desuso, o estado o transformou em um bem de uso dominical ou dominial, que na visão de Carvalho (2017, p. 1090), refere-se aos bens que não têm qualquer destinação pública.

Os bens dominicais são bens alienáveis, ou que podem ser comercializados, uma vez que desafetados. Sendo assim, segundo o autor,

Tais bens somente poderão ser alienados no caso de serem desafetados, quando, então, deixam de ser bens de uso especial (ou comum) e passam a ostentar a qualidade de bens dominicais.(CARVALHO, 2017, p.1092).

Desenvolver esses conceitos aqui, são necessários para podermos propor uma alternativa de destino para aquele imóvel. A princípio, não pensamos em aliená-lo, mas dizer 
que o mesmo, pode e legalmente está disponível para venda. O que queremos propor é que este seja destinado à reforma agrária, uma vez que não é um bem afetado, sem qualquer função social destinada a ele.

\section{Leis brasileiras sobre terras - uma síntese}

Por se tratar do Estado da Bahia, iremos inicialmente nos referenciar à legislação baiana sobre o tema da reforma agrária, podendo já de início, apontar na Constituição Estadual (1989), elementos que concedem ao Estado o poder de deliberar sobre questões de natureza agrária. Assim temos no artigo 171, III, da Constituição Estadual:

Art. 171. São princípios e objetivos fundamentais da política agrícola e fundiária:

III - a garantia do acesso à propriedade da terra a trabalhadores que dela dependem para a sua existência ou subsistência e de suas famílias, como exigência da realização da ordem social; (BAHIA, 1989).

Neste sentido, podemos observar, que se trata de uma determinação dirigida ao Estado.O dispositivo citado faz parte do capítulo III da Constituição Estadual que estabelece a Política Agrícola, Fundiária e a Reforma Agrária, ficando clara a responsabilidade do Estado em desenvolver sua própria política. Esse fato legitima a mobilização das famílias do acampamento Estrela Vive, em uma ocupação que reivindica o assentamento daquelas famílias sobre a área em questão, haja vista o teor da legislação vigente.

Ainda temos o artigo 172 que reforça a obrigatoriedade do Estado da Bahia em desenvolver a reforma agrária em seu território:

Art. 172. É dever do Estado e dos Municípios colaborar na execução da reforma agrária, visando à realização do desenvolvimento econômico e à promoção da justiça social.(BAHIA, 1989).

Não restando dúvida sobre a importância do protagonismo estatal para realização da reforma agrária, cabe às famílias organizadas pelo MST exigir desse Estado a consumação de seus direitos já positivados.

O Estado da Bahiatem todas as ferramentas legais necessárias para realizar o assentamento das famílias acampadas, a reforma agrária como política pública necessita ser aplicada, atingindo assim aqueles que dela precisam.

A lei n. ${ }^{\circ} 3038$ de 10 de outubro de 1972 dispõe de normativas relacionadas às terras públicas, determinando as situações em que à terra deve ser considerada como terra pertencente ao estado da Bahia, como se pode ver no artigo 1. ${ }^{\circ}$ da lei:

Art. $1^{\circ}$ São do domínio do Estado da Bahia as terras:

a) Transferidas ao seu patrimônio pela Constituição Federal de 24 de fevereiro de 1891;

b) do domínio particular abandonadas pelos seus proprietários e as arrecadadas como herança jacente;

c) que não estejam por título legítimo, sob domínio de terceiros;

d) adquiridas por qualquer outro meio legal.(BAHIA, 1972).

É certo que esta propriedade foi adquirida por meios legais, pelo menos é o que se pode concluir ao analisar o registro de imóvel do bem, uma vez que foram compradas 
diversas pequenas propriedadespara aumentar a extensão da terra, que seria utilizada pelo Estado.

As famílias acampadas exigem do Estado o direito de se assentarem naquele bem público, que a princípio, encaramos como sendo um bem desafetado e dominical, o que acaba por elevar a complexidade da realização da reforma agrária, uma vez que desconhecemos assentamentos criados em um bem público dessa natureza.

Diante do problema aqui apresentado, precisamos nosdebruçar sobre o tema da Reforma Agrária, entender o conceito e a classificação, para propor uma alternativa de solução para este caso específico, num esforço de contribuir com as famílias que,há algum tempo, vêm lutando para que a reforma agrária se realize naquela terra.

De acordo com Stédille (2012, p. 659), "Reforma Agrária é um programa de governo que busca democratizar a propriedade da terra na sociedade e garantir o seu acesso, distribuindo-a a todos que a quiserem fazer produzir e dela usufruir".

Neste sentido, a distribuição de terras é uma política pública que deveria ser desenvolvida com mais determinação do Estado, visando uma dinâmica econômica que favoreça o sustento típico ao modo de vida dessas famílias.

Ainda conforme Stédille (2012, p.660), “com base nas diversas experiências de Reforma Agrária, ocorridas em todo o mundo, pode-se aglutiná-las e classificá-las em diferentes tipos de Reforma Agrária". Vamos aqui elencar os modelos referendados pelo autor, tais como: Reforma Agrária clássica; Reforma Agrária anticolonial; Reforma Agrária radical; Reforma Agrária popular; Reforma Agrária parcial; Reforma Agrária de liberação nacional, Reforma Agrária Socialista e, por fim, Políticas de assentamentos rurais.

Podemos considerar as políticas de assentamento rurais o tipo de reforma agrária mais difundida pelos últimos governos brasileiros. Vejamos nas palavras de Stédille (2012) o que significa isso:

São aqueles programas de governo que procuram distribuir terras a famílias de camponeses, utilizando-se da desapropriação ou compra da terra dos fazendeiros. São, porém, limitados na abrangência e não afetam a estrutura da propriedade da terra.(STÉDILLE, 2012, p. 665)

A espécie de reforma agrária que o Estado desenvolverá ao assentar as famílias do acampamento Estrela Vive, possivelmente será esta, a Política de assentamentos rurais, uma vez que não se trata de distribuição de terras em massa, com objetivo de anular o latifúndio no Brasil, mas sim a de atender a uma demanda reivindicativa.

O Estatuto da Terra, lei 4.504/1964, dispõem em seu artigo no artigo $1 .^{\circ}, \S 1$, a seguinte premissa:

Art. $1^{\circ}$ Esta Lei regula os direitos e obrigações concernentes aos bens imóveis rurais, para os fins de execução da Reforma Agrária e promoção da Política Agrícola. $\S 1^{\circ}$ Considera-se Reforma Agrária o conjunto de medidas que visem a promover melhor distribuição da terra, mediante modificações no regime de sua posse e uso, a fim de atender aos princípios de justiça social e ao aumento de produtividade. (BRASIL, 1964).

Neste sentido, há que se observar que essa política de assentamento atende o que está positivado pelo legislador, tendo apenas o sentido de transformar a propriedade da terra, na expectativa de atender uma demanda social e de produtividade.

Podemos afirmar desta forma, que não é obrigatoriamente necessário que o estado desaproprie uma fazenda, para que este faça dessa um assentamento, podendo utilizar um bem 
de uso dominical para este fim, o que seria ainda menos oneroso para os cofres públicos, e neste estudo aqui apontado, temos a fazenda ocupada pelos Sem Terra em Feira de Santana.

A Constituição Federal/88, em seu art. 184, indica a desapropriação para fins de reforma agrária para o imóvel rural que não esteja cumprindo a sua função social, mediante prévia e justa indenização em títulos da dívida agrária, determinação que não serve ao nosso caso concreto, uma vez que não há que se desapropriar um bem estatal.

A partir de uma interpretação sistemática desse dispositivo constitucional, grande parte dos juristas têm sustentado que somente poderá ser desapropriada para fins de reforma agrária, a grande propriedade privada rural improdutiva e que não cumpre a sua função social.

No entanto, o que estamos discutindo é como ficaria a reforma agrária sobre terras públicas, como se daria esse processo, e em quais fundamentos está consolidada essa possibilidade, e especificamente neste caso, em terras que são classificadas como bem público desafetado e dominical.

Propomos que, apesar de ser um bem público, é cabível a exigência do princípio da função social da terra, narrada na constituição, para promover o assentamento dessas famílias, uma vez que não há como justificar a inutilização de um bem tão precioso como a terra, com tantas famílias sem-terra querendo um espaço para plantar e reproduzir suas vidas.

\section{Função social da terra}

Este é um tema de grande destaque entre juristas, tido como um princípio constitucional, ele relativiza o direito de propriedade, tirando o caráter absoluto que, equivocadamente, muitas vezes, o proprietário acredita que tem.

Oliveira (2004, p. 170) nos dá uma lição muito rica sobre o tema, demonstrando como uma diversidade de autores tratam sobre esse assunto, desde suas origens no Direito Constitucional, as mutações do conceito no decorrer da história, até chegar ao significado que temos na atualidade. Nas palavras do autor,

a função social da propriedade não seria se não o concreto modo de funcionar da propriedade, seja como exercício de direito de propriedade ou não, exigido pelo ordenamento jurídico, direta ou indiretamente, por meio de imposição de obrigações, encargos, limitações, restrições, estímulos e ameaças, para satisfação de uma necessidade social, temporal e especialmente considerada. (OLIVEIRA, 2004, p. 170).

Não é pelo fato de a propriedade ser pública, que ela está isenta de observar o princípio da função social. É preciso estar claro que mesmo sendo pública ela deve obedecer aos preceitos constitucionais, estando o patrimônio obrigado a cumprir as determinações a ele incumbidas.

Não fosse a ação dos Sem Terras nos últimos 10 anos sobre a propriedade, com certeza, ela estaria abandonada, não sendo exercida qualquer atividade produtiva sobre a mesma. Aliás, diga-se de passagem, que todo patrimônio físico existente sobre a propriedade, tais como prédios, currais, cercas, açudes devem sua existência aos cuidados dados pelos acampados.

A Constituição Federal do Brasil é a grande limitadora do direito de propriedade, em seu artigo 186, incisos de I a IV temos as obrigações que determinam quando a propriedade está cumprindo com sua função social, vejamos: 
Art. 186. A função social é cumprida quando a propriedade rural atende, simultaneamente, segundo critérios e graus de exigência estabelecidos em lei, aos seguintes requisitos: I - aproveitamento racional e adequado; II utilização adequada dos recursos naturais disponíveis e preservação do meio ambiente; III - observância das disposições que regulam as relações de trabalho; IV - exploração que favoreça o bem-estar dos proprietários e dos trabalhadores.(BRASIL,1988).

Conclui-se então, que o Estado fere a lei ao deixar um patrimônio público como este abandonado, sem nenhum cuidado, sem nenhum proveito ou utilização dos seus recursos, ainda mais quando este nega o direito à terra àqueles que dela tanto precisam para sobreviver.

Podemos ainda indicar como elemento que fortalece essa posição, o dispositivo com existência anterior à nossa atual constituição, e ainda vigente, a lei 4.0504, de 30 de novembro de 1964, que dispõem sobre o Estatuto da Terra. No $\S 1^{\circ}$ do art. $2^{\circ}$, alíneas de "a" a "d", temos o seguinte texto:

Art. $2^{\circ}$ É assegurada a todos a oportunidade de acesso à propriedade da terra, condicionada pela sua função social, na forma prevista nesta Lei. $\S 1^{\circ} \mathrm{A}$ propriedade da terra desempenha integralmente a sua função social quando, simultaneamente: a) favorece $\mathrm{o}$ bem-estar dos proprietários e dos trabalhadores que nela labutam, assim como de suas famílias; b) mantém níveis satisfatórios de produtividade; c) assegura a conservação dos recursos naturais; d) observa as disposições legais que regulam as justas relações de trabalho entre os que a possuem e a cultivem. (BRASIL,1964).

Essas determinações do Estatuto da Terra também são válidas para a propriedade pública, ou pelo menos deveriam ter validade, haja vista que não foi dado ao Estado autorização para desobedecer a lei ou não as cumprir. Entendemos que, apesar do Estado não ter dado qualquer finalidade para aquela área, ele deve ter compromisso com os princípios da função social.

Marés (2006), ao ministrar sobre o tema da desapropriação, nos afirma que o principal objetivo do princípio da função social é direcionar as propriedades que não cumprem com suas obrigações para implementação da reforma agrária. Assim,

A Constituição e o Estatuto da Terra dizem que a propriedade que não cumpre a função social, pode ser desapropriada por interesse social, para fins de reforma agrária. Alguns juristas e muitas decisões judiciais entendem que esta é a sanção que corresponde ao não cumprimento da função social. (MARÉS, 2006, p. 70).

Importante perceber que o autor afirma a necessidade da implementação da Reforma agrária quando este não cumpre sua função social. Entendemos que, se serve para o particular, para a propriedade, a imposição da desapropriação para fins de Reforma Agrária, certamente, essa imposição deveria atingir o bem público.

Essa posição está completamente alinhada à Constituição Federal que, em seu art. 184, assevera:

Art. 184. Compete à União desapropriar por interesse social, para fins de reforma agrária, o imóvel rural que não esteja cumprindo sua função social, mediante prévia e justa indenização em títulos da dívida agrária, com cláusula de preservação do valor real, resgatáveis no prazo de até vinte anos, 
$\mathrm{EM}$

a partir do segundo ano de sua emissão, e cuja utilização será definida em lei.(BRASIL, 1988).

Vejamos que por ser pública, a propriedade não está liberada a não cumprir a lei, ainda mais quando se trata de um imóvel rural, se pressupõe que, por isso, ela está sob o império da mesma. Estando aquela propriedade sujeita à lei, necessário é o cumprimento da reforma Agrária.

Neste caso, a desapropriação é um elemento descartado, a terra já foi inclusive adquirida pelo Estado, no entanto, não é possível afastar o elemento da função social, uma vez que esse é um critério constitucional. O Estado não está fazendo aquela área cumprir sua função social, o bemencontra-se em desuso, inutilizado, o que justifica sua utilização para assentar aquelas famílias.

\section{A proposta de reforma agrária do MST: um projeto que surge das entranhas da luta pela terra.}

A proposta deste eixo é discutir elementos relevantes para uma reforma agrária, mas, principalmente, entre tantas possiblidades, a reforma agrária popular.

\section{Reforma Agrária Popular}

Não podemos deixar de analisar um pensamento propagado pelo Movimento dos Trabalhadores Rurais Sem Terra, denominado de Reforma Agrária Popular. Trata-se de uma proposta de programa agrário aprovado no VI Congresso Nacional do MST, no ano de 2013, realizado na cidade de Brasília.

Nesta proposta, o MST afirma a necessidade de uma agricultura diferenciada do agronegócio, definindo-a da seguinte forma

\footnotetext{
Esse programa sintetiza uma estratégia de resistência ao modelo de agricultura capitalista do agronegócio e propõem um processo de acúmulo de forças, tendo como objetivo a construção de um novo modelo de agricultura, voltado para as necessidades de todo povo brasileiro.(MST, 2013, p. 35)
}

O projeto serve de orientação para que o movimento articule as forças políticas da sociedade em favor da reforma agrária, na perspectiva de mobilização social em torno dessa temática.Assim, nas palavras do MST (2013)

O programa é um importante instrumento na definição das alianças políticas e nas mobilizações unitárias junto às organizações populares e sindicais da classe trabalhadora, do campo e da cidade.(MST, 2013, p. 39).

Essa ideia transforma a proposta em uma ferramenta de uso coletivo, uma vez que não só o MST seria defensor da ideia proposta, mas a sociedade, levantaria essa bandeira como objetivo de ver a reforma agrária ser realizada.

Neste sentido, de acordo com o instrumento metodológico aplicado, os dados levantados através das entrevistas realizadas no acampamento de Feira de Santana, apontam que há uma articulação de forças políticas bastante ampla, uma vezque as famílias se 
relacionam com partidos políticos, com autoridades públicas como vereadores, deputados, senadores, diversas entidades da sociedade civil, professores, universidade dentre outros.

Dentre as ideias defendidas no Programa de Reforma Agrária Popular do MST (2013), temos a de democratizar o acesso à terra, aos bens da natureza e os meios de produção na agricultura a todos os camponeses.

Há nesta proposta, um elemento importante que muito nos interessa, proposto pelo MST (2013) que se resume em

Assegurar que a democratização do uso, posse e propriedade da terra e dos bens da natureza, esteja vinculada aos interesses e necessidades sociais, econômicas, culturais e políticas da população camponesa, especificamente, e, de modo geral, de toda a população brasileira.(MST, 2013, p. 40).

Importante relatar que a fazenda ocupada, apesar do Estado ainda não ter regularizado a situação das famílias, já teve suas terras distribuídas entre as famílias ocupantes, e que já se encontra produtiva, atualmente, oferecendo uma diversidade de alimentos que são comercializados na cidade de Feira de Santana e nas feiras de Reforma Agrária organizadas pelo MST em diversas partes do Brasil. Considera-se essa produtividade na região, um feito importante, haja vista as adversidades enfrentadasno sertão baiano com a seca. Desta forma, cumpre-se o papel social, econômico, cultural e político proposto pela Programa.

Podemos ainda encontrar no Programa do MST (2013) uma questão que tem a ver com uma temática aqui já abordada por nós, que objetivaexigir a devolução de todas as terras públicas que foram griladas por fazendeiros e empresas e destiná-las à reforma agrária.

Neste quesito, as terras públicas não estãoinseridas entre os tópicos do programa como um bem público, uma vez que esta é quase que uma exclusividade da área estudada aqui, ao menos com essas dimensões.

Um outro elemento importante exposto, trata-se da forma como a terra será adquirida pelas famílias.Esta é uma questão muito importante, pois uma vez feita a distribuição das terras, a proposta não é que a família se torne um proprietárioque possa fazer desta uma mercadoria, mas que receba apenas o direito de uso daquela terra, como se pode comprovar abaixo:

Todas as famílias beneficiadas da reforma agrária receberão apenas títulos de concessão de uso, com direito à herança familiar, com dupla titularidade incluindo a mulher, estando proibida a venda das parcelas de terra de reforma agrária.(MST (2013, p. 41)).

Aqui podemos ver que a proposta do Programa é a de que a propriedade permaneça sendo um bem público, e que o Estado apenas concede a permissão para utilizá-la. A terra não é para ser comercializada, é transferida apenas por direito de família, fugindo da lógica que a terra seria um bem financeirizado, podendo ser negociado no mercado.

Nessa perspectiva, os acampados na área da extinta EBDA querem a terra para produzir alimentos, para terem onde morar, onde trabalhar, e prover suas famílias. Não tem propósito de comercializar a terra, querem dela viver.Portanto, a propriedade, sendo pública, pode trazer maior segurança à família, uma vez que esta não está submetida às regras do mercado.

O Programa vai mais adiante, apontando outras questões muito importantes na discussão da reforma agrária, como a água, a produção agrícola, matriz tecnológica, distribuição de riqueza, indústria, política agrícola, educação, infraestrutura, administração do Estado dentre outros temas. 


\section{Germe da Reforma Agrária Popular}

Cientes da condição jurídica e administrativa da propriedade que ocuparam, as famílias resistem sobre a terra, mesmo não tendo qualquer tipo de crédito que fomente a produção, cultivam diversas espécies de alimentos e ainda criam animais de pequeno, médio e grande porte.

O acampamento é um espaço produtivo, onde se cultiva alimentos como legumes, verduras e frutas, também animais como bovinos, caprinos, suínos, aves, além de cavalos, burros, jumentos que são utilizados no trabalho.

Figura 03 - Lavoura de aipim

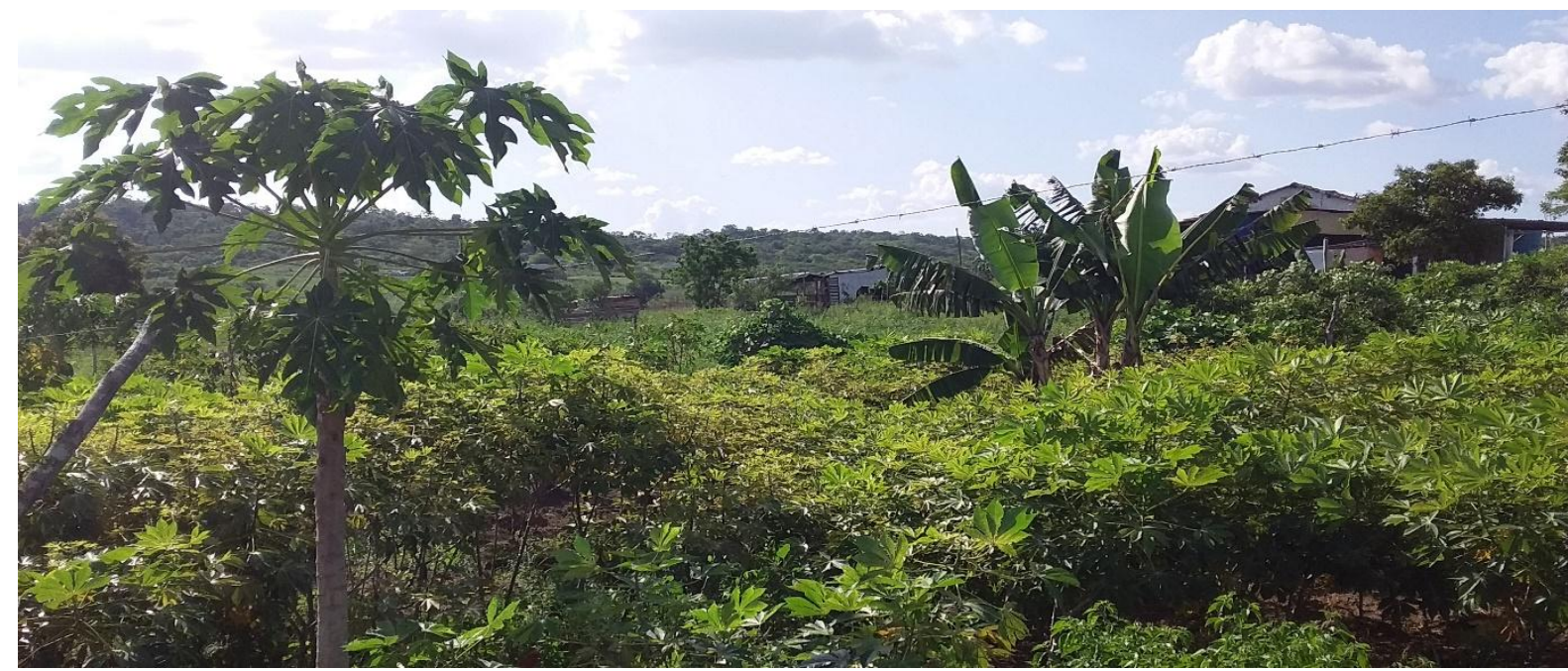

Fonte: José Roberto Silva de Souza (2020)

O setor de produção do acampamento é quem orienta as atividades produtivas, conscientizando as famílias a produzirem sem utilização de adubos químicos e agrotóxicos, inclusive apontando caminhos para uma produção agroecológica, pois estas são bandeiras defendidas pelo MST em todo Brasil. O MST carrega essa discussão como se fosse um princípio ideológico, inclusive para contrapor a proposta do agronegócio.

Nesta direção, um dado importante encontrado e incontroverso é o fato dessas famílias não utilizarem nenhum tipo de insumos químicos para plantarem os alimentos, todos os entrevistados foram unânimes em afirmar que produzem organicamente, sem o uso de agrotóxicos, garantindo, desta forma, um alimento saudável.

Atualmente, a produção é individual, cada uma das famílias tem sua área de terra medindo 50x300, totalizando $15.000 \mathrm{~m}^{2}$ (quinze mil metros quadrados) para plantarem alimentos. As mesmas famílias ainda lidam com animais, utilizando um espaço de 100x300, ou seja, $30.000 \mathrm{~m}^{2}$ (trinta mil metros quadrados). A fazenda está dividida em duas grandes partes, onde, de um lado, se produz alimentos e do outro, animais. No lado onde se produz alimentos, todos os lotes estão cercados,por conta da necessidade de proteger o plantio dos animais. Já o lado da criação de animais, ainda não se encontra totalmente cercado. 
Figura04- Fazenda Mocó

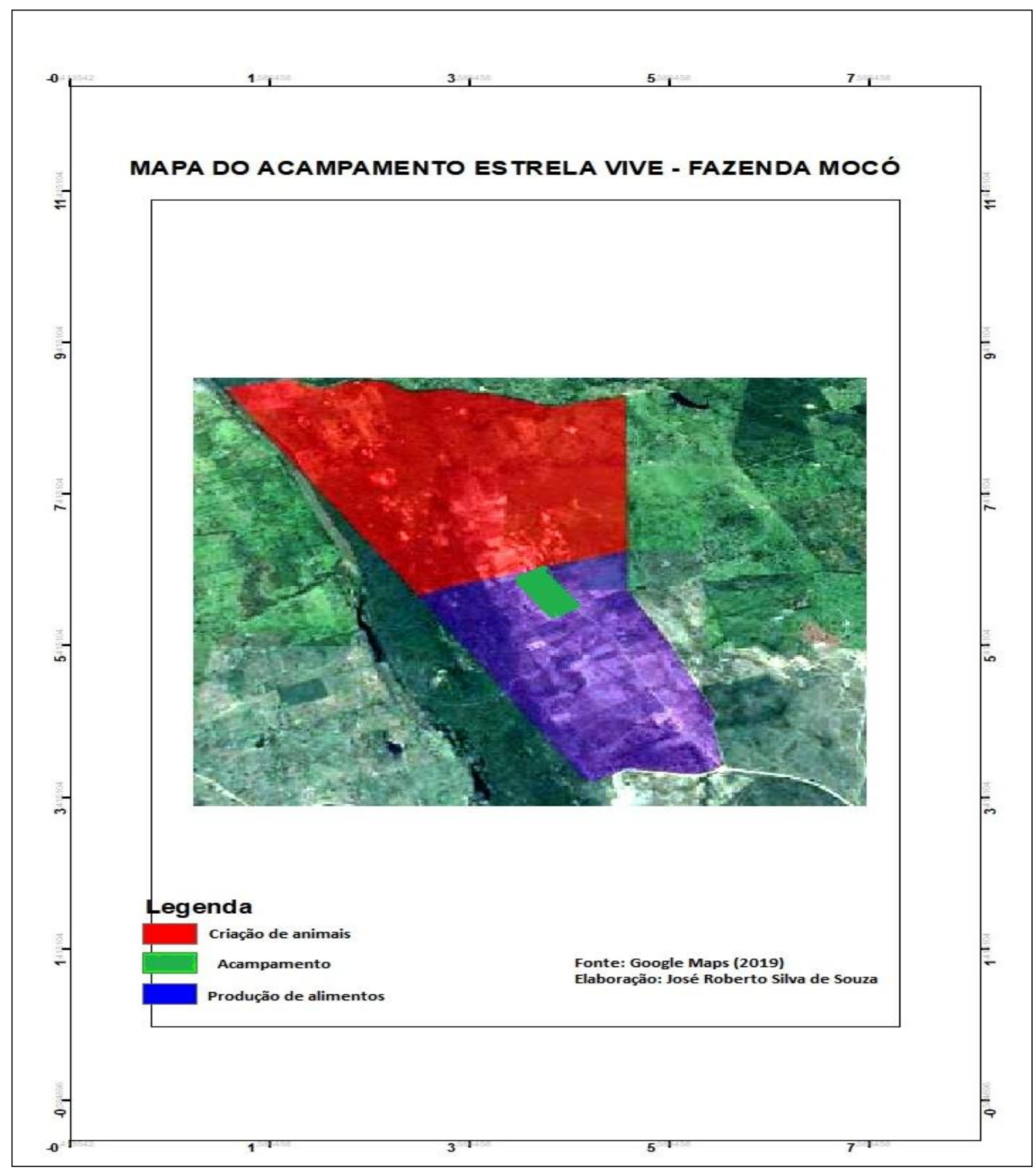

Fonte: Criação do autor. Agosto/2019

Há um espaço que é utilizado pela associação dos acampados para produção de alimentos, conhecido como área coletiva. O conjunto do acampamento é responsável por plantar, aplicar os tratos necessários à lavoura, atividade que é realizada pelo grupo coletivo aqui mencionado anteriormente.

Podemos detalhar aqui, quase toda a produção das famílias.Temos uma variedade na produção, a exemplo de abóbora, milho, feijão, caxixe, batata doce, aipim, andu, tomate, 
EM

quiabo, coentro, pimenta, hortaliças folhosas, como alface e couve. Há plantio de frutas como umbu, cajá, ciriguela, caju, laranja e melancia. Para uma propriedade que foi abandonada pelo Estado, sem qualquer produção, agora, aos cuidados dos acampados, está bem produtiva. A pesquisa não buscou dados quantitativos da produção, apenas se preocupou em saber o que e como se produz.

Figura 05 - Lavoura de feijão consorciada com milho

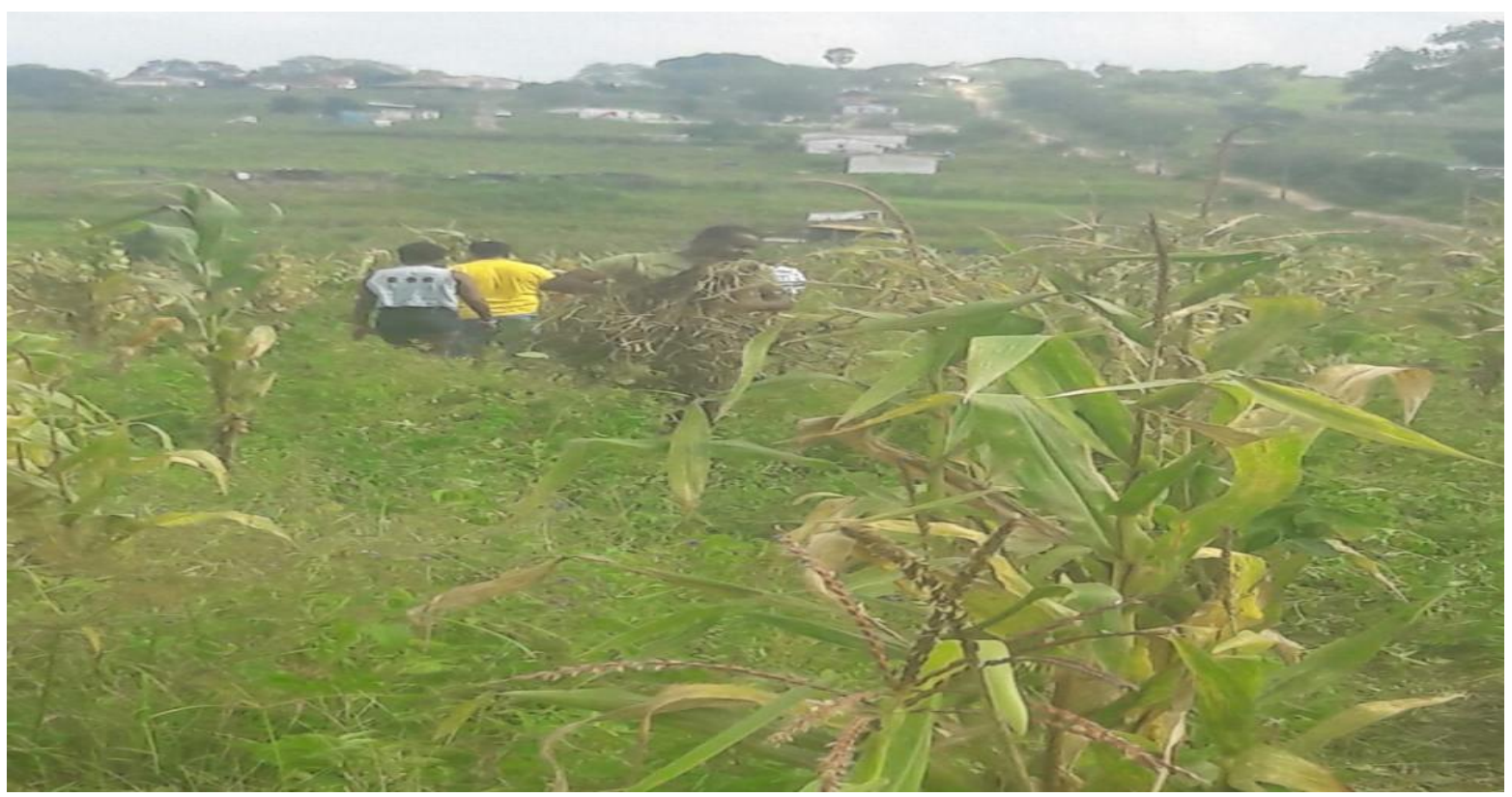

Fonte: José Roberto Silva de Souza (2019)

A produção de alimentos só é possível ser realizada no período de chuvas, com todas mudanças que ocorrem no clima. Segundo os acampados entrevistados, este período ocorre de março a setembro aproximadamente. Nos outros períodos, consegue-se produzir o aipim, por exemplo, por ser uma raiz que pode ser plantada no período chuvoso, mas que consegue resistir às intempéries da seca no sertão por mais tempo. Trata-se de uma observação empírica.

Para os animais, existem os açudes que, no tempo da chuva, armazenam água que será consumida no período da seca e quando estes secam, há nas proximidades da fazenda, correndo ao lado de uma das divisas da propriedade, um rio bem conhecido em Feira de Santana por nome de Jacuípe. Se busca água de carroça, de carro e em um trator que fora deixado na fazenda pela EBDA, mas que os acampados o mantém sempre conservado para utilização.

Figura 06- Açude para captação de água.

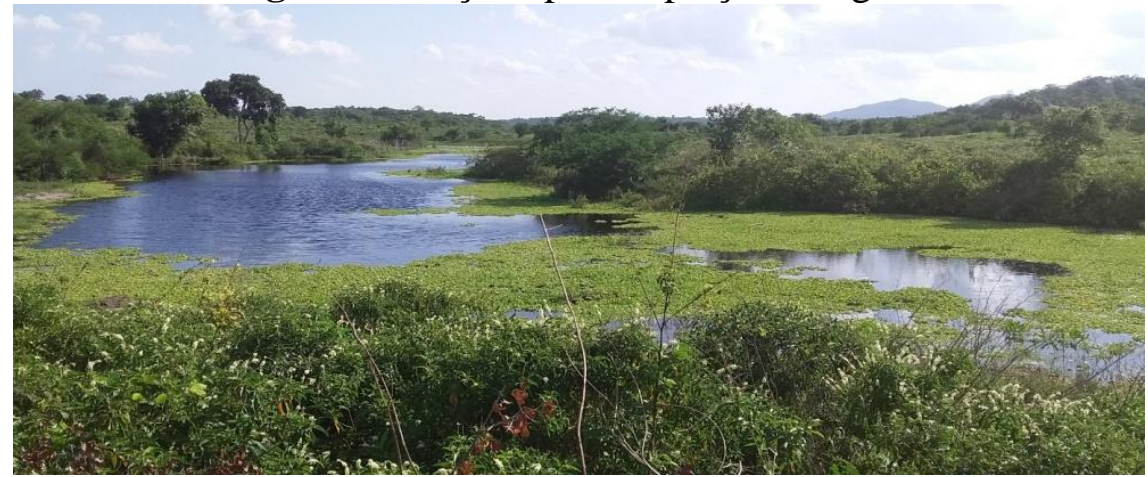


$\mathrm{EM}$

Fonte: José Roberto Silva de Souza (2020)

Há um esforço da coordenação do acampamento em construir um projeto de criação de caprinos e apresentá-lo em algum edital dos governos federal ou estadual, na esperança de obterem recursos para implementação do mesmo. O projeto ainda está em fase de edição, sendo discutido e orientado por técnicos e agrônomos voluntários que se relacionam com acampamento.

Todo esse potencial produtivo que aqui apresentamos é desacompanhado de assistência técnica.As famílias não recebem nenhum tipo de instrução técnica para desenvolver o que cada uma faz. Há uma tentativa de se fazer uma parceria com a Universidade Estadual de Feira de Santana - UEFS, para que esta utilize as instalações deixadas pela EBDA, a fim de promover entre os acampados, formação de natureza produtiva, disponibilizando para isso profissionais do quadro da instituição.

Figura 07 - Criação de animais
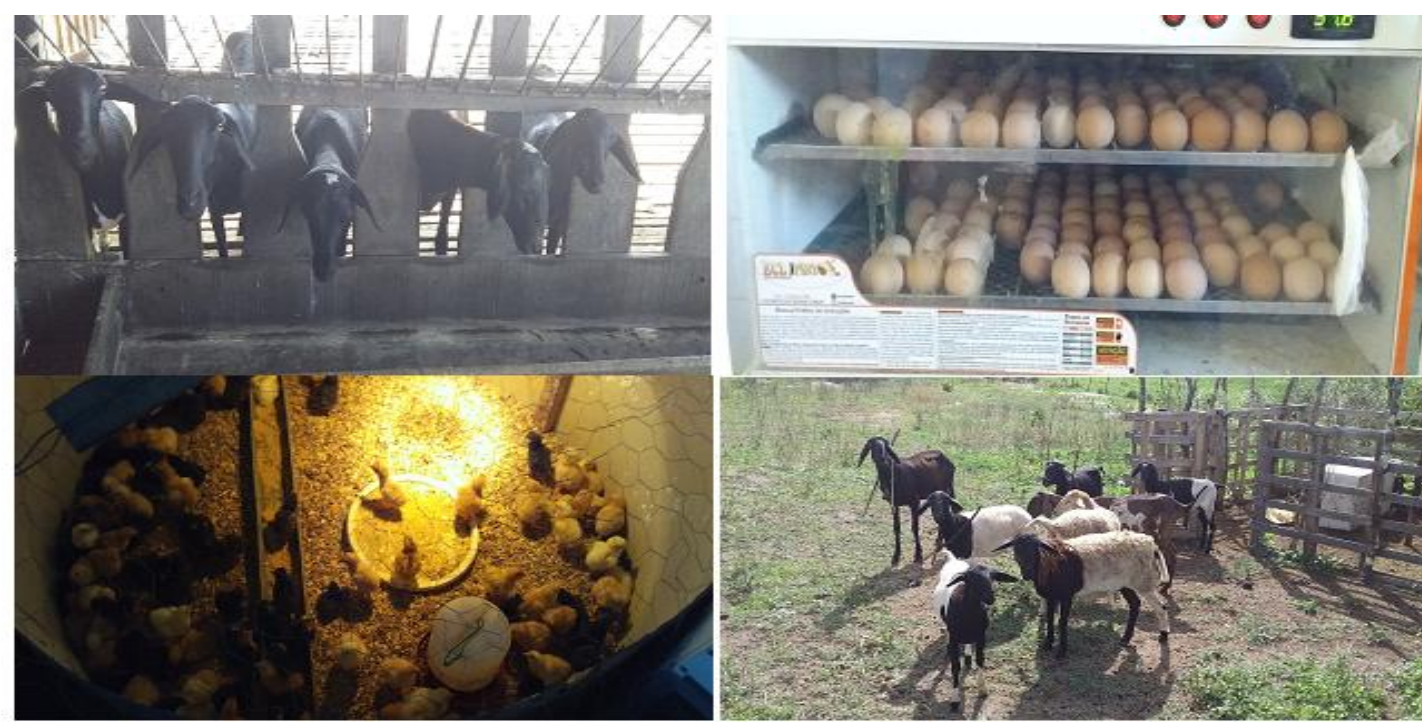

Fonte: José Roberto Silva de Souza (2020)

Alguns professores que já visitaram a fazenda, propuseram desenvolver um curso de extensão e de iniciação científica no local, para que os alunos da universidade, através do aprendizado recebido em sala de aula, possam desenvolver na prática, as teorias sobre os problemas ali encontrados.

Tentamos aqui abarcar de forma resumida e em linhas gerais, neste tópico, as questões que envolvem a produção no acampamento Estrela Vive. Apresentamos aqui os aspectos mais relevantes, captados por meio de entrevista.

\section{Considerações finais}

A ocupação da Estação Experimental é necessária para chamar a atenção da sociedade sobre aquestão agrária do município, uma vez que se trata de uma área de terra pública em desuso pelo Estado e sem qualquer fim social para a mesma.

Entendemos que, de acordo com o Projeto de Lei Municipal do Plano Diretor de Desenvolvimento Urbano e Territorial de Feira de Santana, que expande a área urbana do 
município, o território ocupado não atinge a área de terra aqui estudada, ficando desta forma, localizada na zona rural.

O caso específico do acampamentoEstrela Vive em Feira de Santana trata-se de um imóvel rural que pertence ao Estado da Bahia, mas que não é terra devoluta, uma vez que este foi adquirido através de compra, e transformando em um bem público, agora desafetado pela administração, convertido em bem dominical.

Sendo bem de uso dominical, é possível sua venda ou doação.É inadmissível não dar uma função social ao imóvel, ainda mais se tratando de uma propriedade pública.As famílias nele acampadas podem ser beneficiadas dando ao bem uma função social.

A propriedade imóvel, quando é um bem público estatal, também está submetida à vontade da lei.Ela deve cumprir a função social determinada pela Constituição Brasileira e pelo Estatuto da Terra, não restando dúvida de que a Fazenda Cruzeiro do Mocó deve e precisa estar alinhada com lei, tendo a obrigação de cumpri-la.

A legislação baiana, estadual, autoriza o assentamento das famílias, não restando qualquer motivo para a administração pública baiana não atender à reivindicação dos acampados naquela área.

A reforma agráriaoua política de assentamentos desenvolvida no Brasil, é o meio pelo qual o Estado distribui terras atualmente.Ela está positivada em nosso ordenamento jurídico, autorizando o Estado a realizá-la.

As famílias acampadas, metodologicamente, se apropriaram da terra, organizando-se de forma a garantir a permanência delas sobre o bem, criando representações para que suas decisões sejam assumidas por todos.A organicidade proporciona e facilita um diálogo coletivo no qual todos os membros da comunidade podem e devem opinar sobre as ações do acampamento.

O formato como produzem revela a preocupação e o cuidado necessários para com o meio ambiente e para com a saúde humana, uma vez que são conscientes de que a produção orgânica de alimentos é a alternativa mais saudável para todos.

O método como organizam o acampamento, aponta o modelo de Reforma Agrária desejado pelas famílias e pelo MST de forma geral, uma vez que o Programa de Reforma Agrária defendido por este é fruto da vivência e da prática da luta pela terra, historicamente presente em nosso país.

Com efeito, compreendemos também, na esteira do que entende o MST, que a política pública existente para reforma agrária é insuficiente para atender as demandas das famílias Sem Terra em todo o país. Por esse motivo, se propõe um programa de Reforma Agrária Popular, feita pelo povo e para o povo. Os trabalhadores assentados de Feira de Santana precisam, portanto, de terra, mas especificamente agora, desta terra!

\section{Referências}

BAHIA, Constituição do Estado da Bahia.(1989). Disponível em: http://www.lex.com.br/legis_14128604_Constituição do Estado da Bahia.aspx. Acesso em: 30/01/2019.

BAHIA. DECRETO No 17.037 DE 23 DE SETEMBRO DE 2016. Dispõe sobre o encerramento do processo de liquidação e a consequente extinção da Empresa Baiana de Desenvolvimento Agrícola S.A - EBDA, em liquidação, e da Empresa de Turismo da Bahia S.A - BAHIATURSA, em liquidação. Disponível em: https://www.escavador.com/diarios/382234/DOEBA/executivo/2016-09-24. Acesso em: $\underline{30 / 01 / 2019}$. 
BAHIA. Lei $\mathrm{n}^{\circ} 3.038$ de 10 de outubro de 1972. Dispõe sobre terras públicas e dá outras providências. Disponível em: https://governo-ba.jusbrasil.com.br/legislacao/85821/lei-303872. Acesso em: 30/01/2019.

BAHIA. Lei $\mathrm{n}^{\circ} 13.204$ de 11 de Dezembro de 2014. Modifica a Estrutura Organizativa da Administração Pública do Executivo Estadual e da das Outras Providências. Disponível em: http://leisestaduais.com.br/ba/lei-ordinaria-n-13204-2014-bahia-modifica-a-estruturaorganizacional-da-administracao-publica-do-poder-executivo-estadual-e-da-outrasprovidencias.Acessoem: 30/01/2019.

BRASIL, Constituição da República Federativa do Brasil de 1988. Disponível em: http://www.planalto.gov.br/ccivil_03/constituicao/constituicaocompilado.htm.Acesso em: 30/01/2019.

BRASIL, Lei 10.406, de 10 de janeiro de 2002. Institui o Código Civil. Disponível em: http://www.planalto.gov.br/ccivil_03/LEIS/2002/L10406.htm.Acesso em: 30/01/2019.

BRASIL. Lei $\mathrm{n}^{\circ} 4.504$, de 30 de novembro de 1964. Dispõe sobre o Estatuto da Terra, e dá outras providências. Disponível em http://www.planalto.gov.br/ccivil_03/leis/L4504.htm. Acessoem: 30/01/2019.

BRASIL. Lei $\mathrm{n}^{\circ}$ 601, de 18 de setembro de 1850. Dispõe sobre as terras devolutas do Império. Disponível em: http://www.planalto.gov.br/ccivil_03/LEIS/L0601-1850.htm.Acessoem: 14/03/2020.

CARVAlHO FILHO, José dos Santos. Manual de Direito Administrativo. $28^{a}$ Edição. São Paulo-SP. Editora ATLAS. 2015.

CARvalho, Matheus. Manual de Direito Administrativo. Conforme Novo Código de Processo Civil. Editora Juspodivm. 4a edição. Salvador/BA, 2017.

EBDA - Empresa Baiana de Desenvolvimento Agrícola S.A, Reintegração/Manutenção de Posse Esbulho/ Turbação/Ameaça Civil. Distribuído em 21/05/2009. Disponível em: file:///C:/Users/Jos\%C3\%A9\%20Roberto/Downloads/Processo\%20Ze\%20Roberto\%20(1).pd f.Acesso em: 30/01/2019.

FEIRA DE SANTANA, Lei complementar $n^{\circ} 75$, de 20 de junho de 2013. Fixa os limites interdistritais, amplia o perímetro urbano e delimita 06 (seis) novos bairros do distrito sede do município de Feira de Santana e dá outras providências. Disponível em: https://leismunicipais.com.br/a/ba/f/feira-de-santana/lei complementar/2013/8/75/lei.Acesso em: 30/01/2019.

FEIRA DE SANTANA. Projeto de Lei do Plano Diretor de Desenvolvimento Urbano e Territorial de Feira de Santana. Abril de 2018. Disponível em: http://feiradesantana.ba.leg.br/wp-content/uploads/2018/08/Plco20180003-PDDU.pdf. Acesso em: 30/01/2019.

MARÉS, Carlos Frederico. A Função Social da Terra. Sergio Antônio Fabris Editor. Porto Alegre/ 2003. 
MARÉS, Carlos Frederico. Desapropriação Sanção Por Descumprimento da Função Social?Revista de Direito Agrário, MDA Incra Nead ABDA, Ano 19, n 18, 2006.

MINAYO, Maria Cecília de Souza. O Desafio da Pesquisa Social. In: MINAYO, Maria Cecilia de Souza; DESLANDES, Suely Ferreira; NETO, Otávio Cruz; GOMES, Romeu. (Orgs.). Pesquisa Social, Teoria Método e Criatividade. Petrópolis-RJ: Editora Vozes, 2009. Páginas: 09 a 29.

MST, Movimento dos trabalhadores Rurais Sem Terra. Programa Agrário do MST, 2013.Disponível em: https://mstbrasilien.de/wp-content/uploads/2014/02/Cartilha-Programaagr\%C3\%A1rio-do-MST-FINAL.pdf . Acesso em: 30/01/2019.

OLIVEIRA, Umberto Machado de. Princípio de direito agrário na constituição vigente. Editora Juruá. Curitiba. 2004.

STÉDILLE, João Pedro. Reforma Agrária. In: CALDARTE, Roseli Salete; PEREIRA, Isabel Brasil; ALENTEJANO, Paulo; FRIGOTO, Gaudêncio. Dicionário da Educação do Campo. Rio de Janeiro, São Paulo: Editora Expressão Popular, 2012. Páginas: 659 a 675.

Artigo recebido em 07-07-2019 Artigo aceito para publicação em 13-04-2020 